\title{
GEODIVERSITY AND SUSTAINABLE DEVELOPMENT: GEOPARKS - A NEW CHALLENGE FOR RESEARCH AND EDUCATION IN EARTH SCIENCES
}

\author{
Zouros N.,2 \\ ${ }^{1}$ University of the Aegean,Department of Geography, 81100 Mytilene, Greece,nzour@aegean.gr \\ ${ }^{2}$ Natural History Museum of the Lesvos Petrified Forest, 81100 Mytilene, Greece - lesvospf@otenet.gr
}

\begin{abstract}
Recently a new initiative on Geoparks was established in Europe in close synergy with UNESCO aiming at the protection, promotion and rational management of geological landscapes and significant geosites as well as the sustainable development of their hosting territories. Geoparks are broader territories which include a number of geosites linked in a network which recognize these features as keyelements for the development of geotourism through conservation and management.

Greece is characterized by a complex geological setting and evolution and was subjected to a variety of geomorphological processes, resulting in a high level of geodiversity. As a result a large number of spectacular landscapes and outstanding or unique geosites are present in the country, and they are not properly managed and protected. The Lesvos Petrified Forest Geopark, the very first Greek Geopark, already counts one decade of successful operation. In order to protect and efficiently manage the petrified forest, the Natural History Museum of the Lesvos Petrified Forest was founded in 1994 as the management body of the Lesvos Petrified Forest Geopark. Next, a management plan for geological heritage protection as well as the sustainable development of the area was carried out linking the promotion of geosites, environmental education and the development of geotourism.
\end{abstract}

Key words: Geodiversity, Geoparks management, European Geoparks Network.

\section{Introduction}

Since 1872 when the first national park was established with the creation of the Yellowstone National Park in the USA, in one of the most attractive and emblematic geological localities in the world, a number of Earth heritage sites and landscapes of outstanding scientific, aesthetic and cultural value have been protected for their unique characteristics by national legislation in several countries. Examples include Mount Vesuvius in Italy, the fjords in Norway, the Verdon gorge in France, the Giant's Causeway in Northern Ireland, the Dorset coast in England, Meteora in Greece, Pamukale in Turkey, Uluru in Australia, Niagara falls in Canada, the Devil's tower and the Grand Canyon in the USA, and the Iguazu falls in Brazil/Argentina.

But although exceptional localities of high geomorphological and geological value gain legal protection by national legislation in several countries, abiotic nature in general as well as specific geosites, failed to gain attention autonomously as elements of value for conservation and management within the nature conservation strategies.

The 1972 UNESCO Convention on the Protection of the World Cultural and Natural Heritage provided 
the appropriate framework for the protection of exceptional and unique geological and geomorphological localities. Although UNESCO states that "efforts will be made to balance between the number of cultural heritage and natural heritage properties", the lack of a broader sensitivity on Earth heritage led to a misrepresentation of abiotic nature sites on the World Heritage List. Thus, in spite of its importance for the protection and conservation of some outstanding geosites, it was obvious that the World Heritage Convention was not enough for the protection of the Earth heritage sites around the globe.

The 1991 the Digne conference and the "International declaration of the rights of the memory of the Earth" (Martini 1994) was the starting point for the development of new international initiatives and projects aiming at protecting Earth heritage i.e ProGEO - The European Association for the Conservation of the Geological Heritage or the Malvern International Task Force for Earth Heritage Conservation, (1994).

In 1995 the initiative Global Geosites aiming the systematic inventory of the most important geosites was undertaken by the Global Geosites Working Group, set up by the International Union of Geological Sciences (IUGS) with the support of UNESCO. This initiative intended to identify geosites to be included in a global site database and to aid protection projects, but failed to gain the legal support of national governments and was abandoned in 2003.

The Geopark initiative arose in 1996 during the $30^{\text {th }}$ International Geological Congress held in Beijing. During the Symposium on geological heritage issues were discussed dealing with the progress on geoconservation, effectiveness of the existing organizations and the necessity of the creation of new tools which could produce concrete results on Earth heritage protection and management with the strong involvement and participation of the local communities. As a result, during the following years the Geopark initiative was established and the new concept was defined with the support of the European Union and UNESCO. In June 2000 the European Geoparks Network (E.G.N.) was founded by four European territories, each representing a particular geological and geomorphological heritage: the Reserve Geologique de HauteProvence - France, the Petrified Forest of Lesvos - Greece, Geopark Gerolstein / Vulkaneifel - Germany, and the Maestrazgo Cultural Park -Spain. The four partners signed a convention on Lesvos Island, Greece declaring the creation of the E.G.N and establishing the main characteristics and criteria for the designation of a territory as a "European Geopark", with the main objective being close cooperation in protecting European Earth heritage and promoting a sustainable development of their territories through geotourism (Zouros et al., 2003; Zouros, 2004). During the last decade the Geoparks initiative has expanded globally with 2004 marking the formation of the Global Geoparks Network which operates under the auspices of UNESCO and includes similar regional networks in other continents (UNESCO 2006).

\section{International Geopark Networks}

Geoparks are territories with a particular geological heritage. They are or include nationally protected areas and a number of internationally important geological heritage sites (geosites and geomorphosites) on any scale, or a mosaic of geological entities of special scientific importance, rarity or beauty. These features are representative of the region's geological history and the events and processes that formed it. Geoparks focus not only on the identification and protection of Earth heritage sites, but join this aim with geosite conservation and rational management, improvement of public understanding on abiotic nature and the sustainable local development through geotourism. Geoparks have well-defined limits and comprise a large enough surface area for it to serve real local economic and cultural development. (Zouros et al., 2003; Zouros, 2004; Eder and Patzak, 2004; UNESCO 2004).

The European Geoparks Network (E.G.N.) operating during the last decade with the support of the E.U. and UNESCO, has expanded to include 35 territories across thirteen European countries (France, Ger- 
many, Greece, Spain, Italy, Ireland, U.K., Austria, Romania, the Czech Republic, Portugal, Norway and Croatia) in 2009. The structure of the European Geoparks Network is relatively simple and comprises an Advisory Committee (11 members including representatives of UNESCO, IUGS and IUCN) and a Coordination Committee (comprising of two representatives from each member). Decisions concerning the network are only taken by the Coordination Committee. As part of the Coordination Committee, there is an elected EGN Coordinator and Vice Coordinator to represent the whole Network. They coordinate contacts with other international bodies (E.U., UNESCO, IUGS, IUCN, Council of Europe etc.) and prepare the agenda of the meetings in cooperation with the meeting hosts (Zouros and McKeever, 2009).

Following the successful model of the European Geoparks Network in February 2004, UNESCO established the Global Network of Geoparks (G.G.N.), a global forum of cooperation among National Geoparks worldwide, in order to promote the three goals of conserving a healthy environment, educating the public in Earth Sciences at large, and fostering sustainable economical local development. UNESCO recommends the creation of similar regional networks, reflecting local conditions, elsewhere in the world. Today, besides the European Geoparks Network, the Asia-Pacific Geoparks Network (A.P.G.G.N.) formed in 2007 is also active and other regional networks are under consideration in Latin America, North America and Africa. The Global Geoparks Network consists of regional networks 63 members (1 in Australia, 1 in Brazil, 22 in China, 34 in Europe, 1 in Iran, 3 in Japan, 1 in Malaysia - November 2009).

Protection and sustainable development of Earth heritage and geodiversity through Geopark initiatives contributes to the objectives of Agenda 21, the Agenda of Science for Environment and Development into the twenty-first century adopted by the United Nations Conference on Environment and Development (UNCED, Rio de Janeiro, 1992) and reconfirmed by the World Summit on Sustainable Development 2002 in Johannesburg ${ }^{1}$. In spite of the differences that obviously exist from other protected areas, geoparks meet the general purposes contained in the IUCN - the World Conservation Union definition for protected areas as " an area of land and/or sea especially dedicated to the protection and maintenance of biological diversity, and of natural and associated cultural resources and managed through legal or other effective means" (IUCN 1994). Geoparks as protected territories should not be islands in a sea of development but must be part of every country's national strategy for sustainable management and the wise use of its natural resources, and must be set in a regional planning context, following the declaration of the IV World Congress on National Parks and Protected Areas, in Caracas, Venezuela 1992 (IUCN 1994). The IUCN management categories system provides a common international standard for classifying the many different types of protected area designated in countries around the world, based on primary management objective (Green and Paine 1997). IUCN defined six categories of protected areas. The inclusion of an area in the proposed categories should be assigned on the basis of the primary management objective as contained in the legal definitions on which it was established.

I Strict protection (i.e. Strict Nature Reserve / Wilderness Area).

II Ecosystem conservation and recreation (i.e. National Park).

III Conservation of natural features (i.e. Natural Monument).

IV Conservation through active management (i.e. Habitat/Species Management Area).

V Landscape/seascape conservation and recreation (i.e. Protected Landscape/Seascape).

VI Sustainable use of natural ecosystems (i.e. Managed Resource Protected Area).

\footnotetext{
${ }^{1}$.The Johannesburg Declaration on Sustainable Development was adopted at the World Summit on Sustainable Development (WSSD). The Johannesburg Declaration builds on earlier declarations made at the United Nations Conference on the Human Environment at Stockholm in 1972, and the Earth Summit in Rio de Janeiro in 1992. (Johannesburg Declaration on Sustainable Development, A/CONF.199/20, Chapter 1, Resolution 1, Johannesburg, September 2002).
} 
Within the above mentioned categories, geosites and geological monuments are included in Category III. According to the proposed definition, Category III includes Natural Monuments: protected area containing one, or more, specific natural or natural/cultural feature which is of outstanding or unique value because of its inherent rarity, representative or aesthetic qualities or cultural significance. The area should contain one or more features of outstanding significance (appropriate natural features include spectacular waterfalls, caves, craters, fossil beds, sand dunes and marine features, along with unique or representative fauna and flora; associated cultural features might include cave dwellings, cliff-top forts, archaeological sites, or natural sites which have heritage significance to indigenous peoples). The area should be large enough to protect the integrity of the feature and its immediately related surroundings" (IUCN 1994).

\section{Geodiversity in Greece - protection and management}

Greece is primarily a mountainous country, with seventy per cent of its territory covered by mountains (42 summits over $2000 \mathrm{~m}$ ) and a very long coastline, with a plethora of peninsulas and islands. The complex geological and geomorphological setting and evolution of the Greek orogen, the Hellenides, resulted to the presence of a high geodiversity. GRAY (2004) defines geodiversity as the natural range of geological (rocks, minerals and fossils), geomorphological (landform, processes) and soil features. The Hellenides consist a variety of imbricated tectonic napes of the Alpine orogeny. The Neogene evolution of the area is related with extensive volcanism and active tectonics. As a result, a large number of spectacular landscapes and outstanding or unique geosites are present in the country.

Since 1937 , Greece has started to identify natural areas and place them under special protection. Natural areas are identified as protected areas either according to existing national legislation, or through international conventions and international or European initiatives. Furthermore the sites of the Natura 2000 network are areas of conservation of natural habitats and species of wild fauna and flora of Community interest. In many cases the same area is listed both in national, European and International level. As far as the national legislation is concerned, the declaration of protected areas, in various categories of protection, was based up to 1986 mainly on Forest Law. National Woodland Parks, Aesthetic Forests and Natural Monuments and Landmarks are stipulated by Law No. 996/1971. Wildlife refuges, Controlled Hunting Areas and Game Breeding Stations are stipulated by Law No 177/75, as amended by Law N. 2637/1998. Later on, the Environmental Protection Law was adopted. Law N. 1650/86 following the IUCN definitions further introduced the designation of five categories of protected areas:

- Absolute Nature Reserve Area.

- Nature reserve Area.

- National Park.

- Protected significant natural formation and protected landscape.

- Ecodevelopment Area.

This Law refers clearly to the protection of abiotic components of Nature, but since then very small and timid steps have been taken towards the recognition and protection of the Earth's heritage in Greece.

Some of the most important Greek geosites like the Olympus mount, the Samaria gorge in Crete, the Lavrion ancient mines, the Petrified Forest of Lesvos, the Vikos and Aoos gorges in Epirus, the Vouraikos gorge and the Limnon Cave are included within established protected areas, visited by thousands of visitors each year and benefit from management measures. Others like Meteora - the well known World Heritage site, the Ideon Antron cave, Melidoni and Zoniana caves in Psiloritis Mountain in Crete, the Diros caves in Peloponnesus, the Santorini volcanic caldera, the Nisiros volcano, the Alistrati cave and Aggitis Gorge in Serres etc are established attractions with thousands of visitors each year.

The value of the above mentioned emblematic geosites of Greece is broadly recognized, but the Greek 


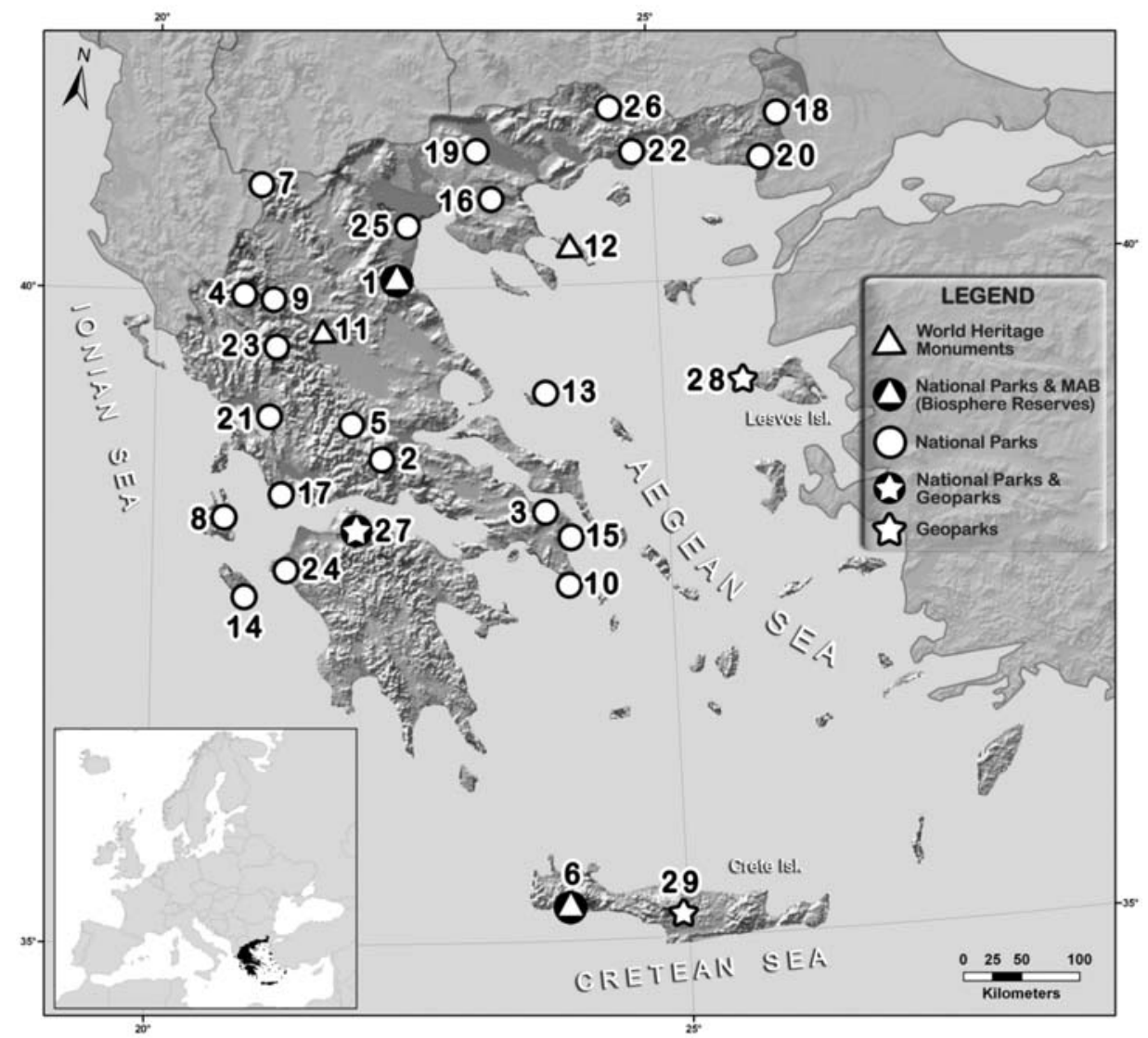

Fig. 1: Protected areas in Greece hosting significant geosites.

(1 - Olympus Mnt. NP, 2 - Parnasos Mnt. NP, 3- Parnitha Mnt. NP, 4 Vikos - Aoos NP, 5 Iti Mnt. NP, 6Samaria NP, 7-Prespes Lakes NP, 8 Aenos Mnt. NP, 9 N. Pindos NP, 10- Sounion NP, 11- Meteora - WHS, 12 - Mnt. Athos WHS, 13 - N. Sporades Marine Park, 14 - Zakinthos Marine Park, 15 - Schinias Marathonas NP, 16 - Koronia - Volvi Lakes NP, 17 - Messolongi - Etolikon NP, 18 - Dadia NP, 19 Kerkini Lake NP, 20 - Evros delta NP, 21 - Amvrakikos NP, 22 - E. Macedonia - Thrace NP, 23 Tzoumerka NP, 24 - Kotichi - Strofilia NP, 25 - Axios-Ludias-Aliakmon delta NP, 26 - Prodopi Mnt. NP, 27 - Chelmos - Vouraikos NP, 28 - Lesvos Petrified Forest Geopark, 29 - Psiloritis Geopark).

state has not yet recognized geosites autonomously within the protected areas as elements of value for conservation and management. Protection and management of geosites is associated to the legal characterization of their hosting territory, either as natural protected area or as area of archaeological interest thus is related mainly to the conservation of habitats and ecosystems or it is attributed to their cultural value. However many important and even outstanding geosites which are not included within the already existing protected areas remain without protection and management.

In spite of the efforts of the scientific community there is no national inventory of geosites. An attempt to create a working group for the protection of the geological heritage in Greece was formed in 1995 by IGME and was enlarged with the contribution of scientists from the universities and other institutions. In 2004 the Geological Society of Greece formed the Commission for the Enhancement of Geological and Geomorphological Heritage, which is coordinating the scientific efforts in geoconservation. 
Several efforts have been made to identify the most important geosites. During the 80's the first attempt was made by the Greek Institute of Geology and Mining Research (IGME) and a list of 50 geosites was submitted to the Ministry of Culture, but without further result. Next, in the frame of the Geosites project, a geosites framework list for South Eastern European countries was prepared (Theodosiou-Drandaki et al., 2003). Aiming to define the most significant geosites of the Greek archipelago was made by the Natural History Museum of the Lesvos Petrified Forest, in collaboration with the Departments of Geology of the Universities of Athens and Thessaloniki and the Department of Geography of the University of the Aegean (1998-2001). This research project aiming at the selection, description and assessment of geosites in the broad Aegean area was financed by the Ministry of the Aegean. The result was the creation of the Atlas of the geological monuments of the Aegean (Velitzelos et al., 2003; Zouros et al., 2004). During 2006-2008 IGME carried out a research project funded by the $3^{\text {rd }}$ Community Support Framework aiming at the selection, description of geosites, the compilation of an inventory of geosites in Greece and the examination of the potential for new Geoparks.

Concrete and viable results in geosite protection geodiversity management in Greece are related to the operation of the first Greek Geoparks. This is a result of the Geoparks management structure operation as well as of the ongoing evaluation procedure which has been established by the European Geoparks Network. In order to achieve high quality standards in Geopark operation and the services provided to visitors, the EGN established an evaluation procedure for all new applicants for membership in the EGN. EGN membership is limited to a period of 4-years after which a revalidation procedure can lead to the renewal of membership. The revalidation follows similar procedures as the evaluation. Greece is represented in both Geopark Networks by three Geoparks: the Lesvos Petrified Forest founding member of the EGN, the Psiloritis Geopark in Crete (2001) and the Helmos-Vouraikos Geopark (2009), which is the youngest member of the EGN. Geoparks should be managed by a clearly defined structure, organised according to the national legislation of each country and with the ability to enforce the protection, enhancement and sustainable development policies within its territory. Management structures in Greek Geoparks do not follow the same structure as they respond to local peculiarities, but they operate in a similar way to achieve their goals. The Lesvos Petrified Forest is managed by the Natural History Museum of the Lesvos Petrified Forest, the Psiloritis Geopark by the Development Company of Psiloritis AKOM and the Helmos-Vouraikos by the Managing Authority of the Helmos-Vouraikos which is a public body of the Ministry of the Environment.

Geoparks are continuously developing, experimenting and enhancing methods for preserving our geological heritage and supporting the development of scientific research in the various disciplines of Earth Sciences. The main purposes of management in Geoparks are the following:

- Scientific research.

- Maintenance of environmental services.

- Protection of specific natural and cultural features.

- Geodiversity and biodiversity protection.

- Tourism and recreation.

- Education.

- Sustainable use of resources from natural ecosystems.

- Sustainable local development.

- Maintenance of cultural and traditional attributes.

\section{Geodiversity management in the Lesvos Petrified Forest}

The Lesvos Petrified Forest Geopark is used as en example to explore the results of geodiversity management in this protected area. The Petrified Forest of Lesvos is declared a protected natural monument (Pres- 
idential Decree 433/1985). With this decree, one marine and four land sections are protected. These sections cover a large area of 150.000 acres in the regions of Sigri, Antissa and Eressos, the marine section around the islet of Nisiopi or Megalonisi and four land regions as well as individual appearances of fossilized trunks.The Barcelona Convention with its attached Protocols was ratified by Greece under Law 855/78 (OG 235/A/1978) and Law 1634/86 (OG 104/A/1986). Under Protocol «On specially protected areas of the Mediterranean» the Lesvos petrified forest and eight other protected areas have been declared as Specially Protected Areas. The greek framework for the protection of natural sites of European Importance through the "Natura 2000 Network" is created, following the E.U. directive (92/43/EC).The area of the Petrified Forest is included among the sites that constitute the National List of the Natura 2000 Network, after it was included in the Western Peninsula Lesvos - Petrified Forest region (code GR 4110003).

The Natural History Museum of the Lesvos Petrified Forest, aiming at protection and efficient management of the Lesvos Petrified Forest, was founded in 1994. It is a non-profit organisation and the management structure of the Lesvos Petrified Forest Geopark. Its seven-member board encompasses representatives of the state (Ministry of Culture, Ministry of Environment), the local authorities, universities and representatives of the local community. Its scientific, technical and administrative staff includes 10 permanent and 25 temporary employees. The Lesvos Petrified Forest Geopark comprises a core zone $(15,000$ hectares of the petrified forest protected area) and a broad buffer zone (more than 20,000 hectares of the central volcanic terrains).

Geodiversity management is based on a strategic plan for the sustainable development of the area. This plan links the protection, conservation and promotion of geosites with the development of geotourism and educational activities. The Lesvos geopark has also created links with local tourist enterprises, artisans and women's cooperatives producing local food and drinks. Integrating Earth heritage as an integral part of the territorial identity and combining all the existing resources, this strategy creates a new quality offer both for local stakeholders and geopark visitors. The Geopark strategic plan takes into consideration the existing natural and cultural resources, tangible and intangible, in order to attract not only those interested in Earth heritage monuments but also the general public together with certain focus groups. Thus it aims at raising public awareness of abiotic nature and promoting the Geopark as an ideal destination for recreation and education.

In the Lesvos Geopark, the presence of important geosites (i.e. fossil sites, volcanic structures, craters, and thermal springs, tectonic, erosional and coastal geosites) is accompanied by enchanting landscapes, wetlands, sites of natural beauty and ecological value, protected biotopes and biological reserves, archaeological monuments, medieval castles and monasteries, picturesque villages, local traditions and gastronomy. The Geopark area is also the birthplace of famous people of art and literature such as the great poet Sappho and the philosopher Theophrastus of Eressos who is regarded as the father of botany and mineralogy, the singer and citharede Arion, the poet and citharede Terpander of Antissa who lived in about the first half of the 7th century BC and is regarded as the real founder of Greek classical music and of lyric poetry, and the painter G. Iakovidis (1853-1932). The promotion of the interaction between abiotic and biotic nature, geology and life, nature and culture is very important to call attention to the importance of Earth heritage conservation and protection for nature conservation and administration of territorial identity.

Scientific knowledge and research is a prerequisite for successful geodiversity management as it is necessary in all fields of activities i.e. geosite identification and mapping, conservation, exhibition, interpretation, communication and promotion. Thus a research team was formed and five permanent researchers in Earth and environmental sciences were engaged to support the Geopark's operation. The Museum research team has worked in close collaboration with the Universities of the Aegean, Athens and Thessaloniki since its foundation. This collaboration has proved to be essential towards 
geosite and fossil identification and interpretation for the public. The Museum also established collaboration agreements with other museums, universities, research institutes and Geoparks in Greece and abroad. Many researchers, $\mathrm{PhD}$, master and undergraduate students have used the opportunity of a placement at the Museum and to collaborate in a variety of research projects in the broader field of Earth and environmental sciences.

The Museum exhibitions, the Aegean geosite inventory, the Lesvos geosite map as well as the creation of installations and activities for geosite protection and interpretation are based on the results of this scientific research. Several geosites were identified within the overland area, along the coast and in the marine zone of the Lesvos Petrified Forest Geopark. Paleontological excavations in the petrified forest area, ongoing since 1997, include systematic excavations within the parks as well as in rescue excavations in sites of public or private construction within the protected area. Geosite protection measures comprise regular maintenance (fencing, cleaning) and janitor services to protect geosites against abuse and vandalism, geosite monitoring providing the necessary measures and protective installations against weathering and erosion, treatment of vulnerable geosites with annual conservation and protective measures (preparation, sealing). Conservation work on fossil plants started in 1998 by the Museum conservation team both for in situ fossil trees located in the parks, and in the conservation labs for smaller objects kept within the museum premises.

The Museum and its exhibitions were designed with two objectives: the first to offer the best conditions for the exhibition and interpretation of the fossil plant exhibits of the Lesvos Petrified Forest and secondly to be a Museum that welcomes and befriends its visitors. Scientific research, mapping and excavations result in the exhibits that constitute the main part of the museum collections while another essential component comes from donations which provide data for the interpretation of the processes and phenomena that form the Earth's crust evolution in the Aegean region.

The creation of the Petrified Forest visiting parks, the creation of geotouristic trails linking sites of interest within the geopark, the placement of geosite interpretation panels and info points are essential elements for the operation of the Lesvos geopark, providing to the Geopark visitors access to the geological heritage and information of the processes that led to the creation of this natural monument 20 million years ago. The main geotouristic infrastructure in the Lesvos geopark are the "lava paths" that lead visitors along the ancient path of the pyroclastic flows from the main volcanoes to the Petrified Forest. These are footpaths that link the various geosites and other sites of interest throughout the geopark. Panels along the footpaths provide information about the different geosites that the visitor will encounter along the way. On entering the Lesvos geopark region, signs along the Mytilene-Kalloni-Sigri road direct the visitor towards the Petrified Forest and demarcate the borders of the protected area. Walking trails start from different points along the main road.

Scientific results are the basis for the development of a broad range of activities for the Lesvos geopark that assist in raising public awareness about the importance of geosites, including guided tours in the petrified forest parks, the development of environmental education programmes on geosites, the organisation of summer schools and field camps for university students, the establishment vocational training seminars for unemployed young people, the publication of books and field guides, the production of CDs and DVDs and the promotion of monumental geosites.

Thus not only the geopark visitors but also the local population and especially the your students living within the geopark realise that certain "rocks" in the vicinity of their houses represent remnants of outstanding phenomena and processes and demonstrate the geological history of their living area. In this way geoforms and rocks gain a new identity for the people and at the same time become objects to be respected and protected. 


\section{Conclusions}

Geology and landscape have profoundly influenced society, civilization, and the cultural diversity of our planet but geosites failed to gain attention autonomously as elements of value for conservation and management within the nature conservation strategies.

The Geoparks Network is a new initiative aiming at geodiversity management and protection adopting a holistic approach in nature conservation. The main goal of geoparks is to improve and augment the recognition, protection, conservation and promotion of their geological and geomorphological features, but their interest also concerns the biological elements and cultural sites they contain. The Geoparks initiative adds a new dimension to the 1972 Convention concerning the Protection of the World Cultural and Natural Heritage by highlighting the potential for interaction between socio-economic and cultural development and conservation of the natural environment (UNESCO, 2006). Geoparks address the strong need for the effective management of important geological sites and for the sustainable economic development of rural areas through the development of geotourism thus enhancing the value of their Earth heritage, landscapes and geological formations. For the effective management of a Geopark it is essential to establish a solid, flexible and powerful management structure that will be able to decide on the protection, promotion, economic development and progress of the geopark.

With the Natural History Museum of the Lesvos Petrified Forest as its management body, the Lesvos Petrified Forest European and Global Geopark can provide a good example of successful geodiversity management in a Geopark territory. The Geopark management plan is based on scientific results and includes a variety of activities aiming at geoconservation, geosite interpretation and promotion, the creation of geotouristic and educational activities and local development in order to raise public awareness of the values of Earth heritage conservation.

\section{References}

Dudley, N., (Editor), 2008. Guidelines for Applying Protected Area Management Categories. Gland, Switzerland: IUCN. $\mathrm{x}+86 \mathrm{pp}$.

Eagles, Paul F.J., McCool, Stephen F. and Haynes, Christopher D.A., 2002. Sustainable Tourism in Protected Areas: Guidelines for Planning and Management. IUCN Gland, Switzerland and Cambridge, UK. xv + 183pp.

EKBY, 2009. Protected areas in Greece. Available online at: http://www.ekby.gr

European Geoparks Network EGN Magazine. No 1-6.Available online at: http://www.europeangeoparks.org

Eder W., Patzak M., 2004 - Geoparks - geological attractions: a tool for public education, recreation and sustainable economic development. Episodes, 27/3, 162-164.

Gray M., 2004 - Geodiversity, valuing and conserving abiotic nature. J. Wiley \& Sons, Chichester, 434 p.

IUCN, 1994. Guidelines for Protected Area Management Categories. CNPPA with the assistance of WCMC. IUCN, Gland, Switzerland and Cambridge, UK. x + 261pp. Available online at: http://www.unep-wcmc.org/protected_areas/categories/eng/index.html

Mc Keever P. and Zouros N., 2005. Geoparks: Celebrating earth heritage, sustaining local communities. Episodes vol. 28, No 4, p. 274-278.

Mac Keever P., Zouros N., Patzak M., 2009. Global Network of National Geoparks. World Heritage No 52, 54 .

Martini G. (Ed.), 1993 - Actes du premier symposium international sur la protection au patrimonie géologique [Proceedings of the First Symposium on Earth Heritage Conservation], Digne, France, 1116 June 1991. Mémoires de la Societé géologique de France, numéro spécial 165, 276 p. 
Theodossiou-Drandaki I., Nakov R., Wimbledon W.A.P., Serjani A., Neziraj A., Hallaci H., Sijaric G., Begovic P., Petrussenko Sv., Tchoumatchenco Pl., Todorov T., Zagorchev I., Antonov M., Sinnyovski D., Diakantoni A., Fassoulas Ch., Fermeli G., Galanakis D., Koutsouveli A., Livaditi A., Papadopoulou K., Paschos P., Rassiou A., Skarpelis N., Zouros N., Grigorescu D., Andrasanu Al., Hlad Br., Herlec U., Kazanci N., Saroglu F., Dogan A., Inaner H., Dimitrijevic M., Gavrilovic D., Krstic B., Mijovic D. , 2003 - IUGS Geosites project progress - a first attempt at a common framework list for South Eastern European Countries. Proceedings of the conference "Natural and cultural landscapes". The Geological Foundation, Dublin, Ireland, 9-11/9/2002, 81-89.

UNESCO, 2006 - Guidelines and Criteria for National Geoparks seeking UNESCO's assistance to join the Global Geoparks Network, Paris, January 2006. Internal document, 10 p.

Velitzelos, E., D. Mountrakis, N. Zouros, N. Soulakellis, 2003. Atlas of the geological monuments of the Aegean. Ministry of the Aegean, Adam editions, Athens p.352.

Zouros N., 2004. The European Geoparks Network. Geological heritage protection and local development. Episodes, 27/3, 165-171.

Zouros N., 2005. Assessment, protection and promotion of geomorphological and geological sites in the Aegean area, Greece. Géomorphologie: relief, processus, environnement, no 3, 227-234.

Zouros N., 2007. Geomorphosite assessment and management in protected areas of Greece. Case study of the Lesvos island coastal geomorphosites. Geographica Helvetica, Jg.62, Heft 3/2007, 169-180.

Zouros N. Martini G. Frey M.L., 2003. Proceedings of the $2^{\text {nd }}$ European Geoparks Network Meeting, Lesvos 3-7 October 2001, p. 184.

Zouros, N., N. Soulakellis, D. Mountrakis, E, Velitzelos, 2004. Atlas of the geological monuments of the Aegean. Contribution to the protection and promotion of geological heritage in Greece. 32nd International Geological Congress, 20-30 August 2004, Florence, Abstracts, p. 224.

Zouros N. and McKeever P., 2009. European Geopark Network and Geotourism. The $3^{\text {rd }}$ International Symposium on the Development within Geoparks. Geo-heritage Protection and Cooperation. Aug. 2225, 2009.Tai'an City, Shandong Province, China. 